\section{Frykten for å vise hvem vi er}

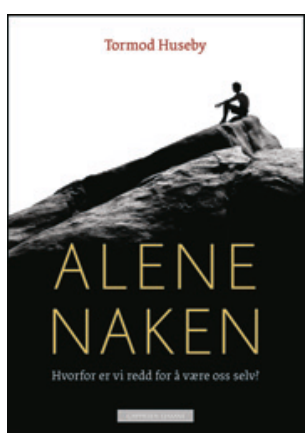

Tormod Huseby

\section{Alene naken}

Hvorfor er vi redd for å være oss selv?

277 s. Oslo: Cappelen Damm, 2015

Pris NOK 349

ISBN 978-82-02-47138-5

Rammeverket i denne utgivelsen er pasienthistorier fra forfatterens praksis som privatpraktiserende psykiater i Oslo. Felles for disse historiene er at personene på ulike vis har brukt mye krefter på å skjule hvem de er, av frykt for å bli avvist. Forfatteren beskriver hvordan det kan være frigjørende å bryte med dette mønsteret. Han prøver å forstå pasientenes livshistorier ut fra deres barndom og oppvekst, preget av mangel på bekreftelser og omsorg, og han fortolker utviklingen ut fra psykodynamisk teori. Pasientenes situasjon bedres som følge av behandling, og dette gir et optimistisk syn på mulighetene for utvikling og vekst $i$ voksen alder.

Et viktig tema for forfatteren er at han mener mange behandlere er for redde for å vise seg som levende mennesker for sine pasienter. Han mener dette kan redusere behandleres muligheter for å hjelpe mange pasienter. Han har eksempler på at terapeuters rolle som «tabula rasa» kan ha medført at pasienter har trukket seg fra behandling, og at møtet med en mer personlig behandler ble opplevd som mer fruktbart.

Et originalt innslag er at forfatteren også refererer hendelser fra eget liv av mer eller mindre personlig karakter, for å vise det allmennmenneskelige aspektet ved psykiske lidelser. Boken avsluttes med en solid referanseliste, som omfatter alt fra innlegg i avisen til vitenskapelige artikler, men referansene skrives ikke fortløpende i teksten.

Pasienthistoriene er interessante og godt beskrevet, og de gir gode muligheter for gjenkjennelse og identifikasjon. Forfatteren beskriver i liten grad hvordan han tenker at endring har skjedd, og det hadde vært interessant om vi kunne få vite litt mer om hva han tenker om dette. Noen av de personlige eksemplene er gode og illustrerende, andre oppleves litt på siden.

Boken har også et kapittel om biologiske årsaker, men dette faller utenfor resten av innholdet og oppleves som unødvendig. Jeg har stor sans for hans tanker om at behandlere kan våge å vise mer av seg selv, selv om grensen mellom privat og personlig ikke alltid er lett å finne.

Forfatteren angir selv ingen spesiell målgruppe. Boken kan leses uten forkunnskaper i psykiatri eller psykologi, da alle viktige begreper forklares godt underveis. Jeg anbefaler den til den opplyste allmennheten.

Egil W. Martinsen

Overlege, Klinikk psykisk helse og avhengighet

Oslo universitetssykehus

\section{Bra om helseledelse}

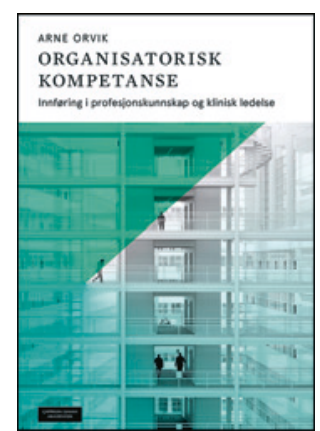

Arne Orvik

Organisatorisk kompetanse

Innføring i profesjonskunnskap og klinisk

ledelse. 376 s, tab, ill. Oslo: Cappelen Damm

Akademiske, 2015. Pris NOK 539

ISBN 978-82-02-45593-4

Arne Orvik er førstelektor ved Høgskolen i Ålesund med fagområdene organisatorisk kompetanse, helsepolitikk, helseledelse, samhandling og tverrfaglig, interorganisatorisk samarbeid. Første utgave kom i 2004. Denne nye, reviderte versjonen har en mer tverrprofesjonell fagprofil.

Forfatteren gir en innføring i profesjonskunnskap og ledelse for helsepersonell. Målgruppen er primært helsefagstudenter i bachelorutdanningen, men også studenter på masternivå.

Organisatorisk kompetanse er skrevet i en utforskende og analytisk stil. Forfatteren tar opp rolleforventninger og kompetansebehov, nøkkelbegreper i ledelse, pasientperspektiv, produksjonsperspektiv og profesjonsperspektiv, organisasjonsformer, samhandling og endringsprosessens faser. Han avslutter med en grundig gjennomgang av klinisk ledelse.

Oppbyggingen er god, med over 400 kildeanvisninger. Boken dekker det aller meste av hva som er skrevet om helseledelse på norsk, i tillegg til at den har mange nyttige henvisninger til internasjonal litteratur på området. Hvert kapittel avsluttes med en rekke spørsmål og problemstillinger til refleksjon og diskusjon. Det gjør den spesielt velegnet for studenter.

Helsepersonell skal ivareta kvaliteten på pasientbehandlingen samtidig som de skal sørge for effektivitet og produktivitet. Den kliniske hverdagen er kompleks. Det er ikke lenger tilstrekkelig å være en god kliniker. Dagens helsepersonell må også kunne organisere og lede. Undervisning i ledelse har vært relativt lite prioritert i grunnutdanningen av leger i Norge. Det er i ferd med å endre seg. Derfor er denne utgivelsen et kjærkomment tilskudd til lærebøker på området.

Jeg kan trygt anbefale boken til alle typer helsepersonell som ønsker å kvalifisere seg til lederoppgaver i helsevesenet. Ved Universitetet i Bergen vil vi ta den i bruk i det erfaringsbaserte masterstudiet $i$ helseledelse for leger og annet helsepersonell som vil ta videreutdanning i helseledelse, helseøkonomi og kvalitetsforbedring. Vi vil også anbefale den til medisinstudenter som etterlyser gode og oppdaterte lærebøker om ledelse.

\section{Kjell Haug}

Professor, Institutt for global helse og samfunnsmedisin Universitetet i Bergen 